European journal of American studies

Special Issue: Media Agoras: Islamophobia and Inter/ Multimedial Dissensus

\title{
Media Agoras: Islamophobia and Inter/Multimedial Dissensus. Introduction
}

\section{Elena Furlanetto and Frank Mehring}

\section{(2) OpenEdition}

\section{Journals}

Electronic version

URL: https://journals.openedition.org/ejas/16141

DOI: $10.4000 /$ ejas. 16141

ISSN: 1991-9336

Publisher

European Association for American Studies

Electronic reference

Elena Furlanetto and Frank Mehring, "Media Agoras: Islamophobia and Inter/Multimedial Dissensus. Introduction", European journal of American studies [Online], 15-3 | 2020, Online since 29 September 2020, connection on 21 September 2021. URL: http://journals.openedition.org/ejas/16141 ; DOI: https://doi.org/10.4000/ejas. 16141

This text was automatically generated on 21 September 2021

Creative Commons License 


\title{
Media Agoras: Islamophobia and Inter/Multimedial Dissensus. Introduction
}

\author{
Elena Furlanetto and Frank Mehring
}

Agora, n.: A public open space where people can assemble, esp. a marketplace, originally in the ancient Greek world; the structures enclosing such a space.

oxford English Dictionary

1 During the last years, different forms of Islamophobia have become common and continue to infiltrate law, politics, and culture. Although the term has moved, as Khaled A. Beydoun rightly points out, from the academic discussions into the realms of social media platforms and headline news of national newspapers (189), Islamophobia continues to be a slippery term, sometimes employed without clear definitions, in ways that are too generic or reductive, or altogether avoided (Bleich 180); it is a relatively recent word synthesizing ancient forms of hatred. ${ }^{1}$ To this day, Islamophobia emerges from a variety of studies "as a largely ambiguous phenomenon..., at times indistinguishable from other similar phenomen[a], at times both nondescript and indistinct" (Allen 123). While George Salaita prefers replacing it with the "more accurate" "Anti-Arab racism" (245) and Fred Halliday with "anti-Muslim" (165), ${ }^{2}$ others, such as Martina Pfeiler in this special issue, retain it precisely because of its ambiguities.

2 This special issue does not aim for a conclusive definition but hopes to contribute to the theorization of Islamophobia by adding a number of elements to the discussion. Islamophobia became an essential part of public discourse in the U.S. after 9/11, contributing to a culture of patriotic self-fashioning: In many cases, Americans defined themselves in opposition to Islam, moreover, the "highly emotive issue" (Allen 376) that informed the discourse over Islamophobia was fueled by a sense of fear of Islam. In fact, most existing definitions prioritize fear (see Lee et al., Abbas, Zúquete). Implied in the etymology of the word "Islamophobia" and enhanced by the contiguous discourse of terrorism, Islamophobia has become discursively anchored in the field of fear and terror. ${ }^{3}$ But while the legacy of terror reverberates in most manifestations of 
Islamophobia, hate and anger have always been parallel driving forces within this discourse. ${ }^{4}$ Accordingly, Khaled Beydoun understands Islamophobia as "a modern extension of a deeply embedded and centuries-old form of American hate" (6). ${ }^{5}$

3 This special issue will concentrate on Islamophobia as a public narrative that became ubiquitous in American mainstream media since the early 2000s and penetrated all channels of modern communication in the Western world. We understand Islamophobia as a cultural phenomenon, crafted and circulated through medial practices such as television shows, films, literary texts, performances, videos, and Internet blogs. The term has been associated with at least two implications: it can function as a) a signifier for fear of Islam and its followers (see Lee et al., Abbas, Zúquete); b) a cultural marker for Muslimness related to dress, rituals, language etc. (Iqbal, Love). Islamophobia leads to a perception and reaction that identifies Muslims with the potential danger of terrorist attacks. Zafar Iqbal underscores that the notion of Islamophobia is by no means a passive response to a threat, but an irrational fear generative of aggressive behaviors and offensive actions (91). Since Islamophobia nowadays is for the most part triggered by mediation and remediation (Bolter and Grusin), studying the function, construction, and circulation of Islamophobic markers in and through media is imperative (82). In the early months of 2020, episodes of racial violence in the U.S. against African Americans like Ahmaud Arberry, George Floyd, and Breonna Taylor caused worldwide upheavals and even mainstream voices appeared ready to denounce the American media landscape as overwhelmingly racist. The focus on racially motivated violence has also encouraged reflections on racism as a problem that exceeds blatant macro-aggression, seeping into everyday-life interactions and automatic reflexes. In the realm of cultural criticism, while openly racist cultural products are met by many with uncompromising rejection, the ambivalence of other texts that parade progressive politics and proverbial "good intentions" also calls for urgent scrutiny. As we write, Donald Trump, who has made hatred against Islam a propeller of his campaign, still holds the presidency.

Although Islamophobia and related manifestations of Orientalism, like other cultural constructions, have always depended on a degree of media exchange, our approach to Islamophobia builds on inter- and multimedial constellations, asking: how is Islamophobia mediated? How do media systems of the twenty-first centurycharacterized by the flow of content across media platforms and the interconnection of multiple media industries (Jenkins 2)-forge Orientalism and Islamophobia into new shapes? Contributions in this volume read film, television, performance art, graphic novels and their film adaptations as "media agoras." 6 The term "agora" refers to an open space in ancient Greek cities serving as an assembly area and a place for commercial, civic, social, and religious activities. In its extended use, the term refers to an "assembly for discussion or decision; (hence) any environment or world of social intercourse, exchange, or commercial dealings" (OED2). In this volume on Islamophobia, we refer to virtual agoras where a convergence of media enables diverse ideological positionings, encouraging complex, even contrastive responses to public discourses. More specifically, this publication investigates the predisposition of multiand intermedial narratives to complicate the expression of consensus or dissensus: thus, single multi- or intermedia texts displaying contrastive interpretations of or articulating dissensus towards Islamophobia can be imagined as "media agoras." Films and TV productions in particular-as inherently multimedial texts and especially receptive to intermedial aesthetics-but also graphic novels and performance art, offer 
a privileged surface for medial interactions and collisions. In Convergence Culture (2006), Henry Jenkins notes that a culture where a plethora of old and new media converge on a daily basis, as if on a virtual agora, automatically expands the number of voices that intersect in the public sphere, creating the impression that debates may be ruled by logics of "access, participation, reciprocity," or even profound contradiction (Jenkins 208). In addition, as Tim Marr notes, "migrating Muslim cultural practices have circulated in the United States through different and at times contradictory registers, and these lines of connection have been recently multiplied through social media" (267). These media agoras that we are about to explore provide a discursive space for a more planetary involvement emphasizing the transnational beyond the boundaries of nations and the imaginary constructions of homelands.

5 A similar point can be made with regards to intermedial and multimedial texts, in light of their potential to host interactions, interferences, and productive tensions between media, particularly in our digital age (see Rippl, Bolter and Grusin). A single text containing diverse media-each pervaded by its own mythologies, politics, and histories-gives rise to multivocal narratives that speak in a variety of voices, and may display dynamics of internal accord and disaccord. Multimedial texts that offer coexisting and yet dissonant responses to public debates may disrupt cultural orthodoxies, thus becoming a site of resistance. This is even more the case for intermedial texts, to which scholars have acknowledged an inherently subversive quality. As early as 1998, Dick Higgins's Horizon: The Poetics of Intermedia claimed that "an intermedium was not intended to conform to the pure medium" (22). Due to this formal hybridity, Birgit Neumann reads intermediality as a "transgressive practice" (514) that challenges notions of homogeneity, unity and sameness, enabling the possibility to critique cultural orthodoxies not only through content, but also through form. Conversely, however, tensions within intermedial configurations may also invalidate the critical impetus of texts that brand themselves as disruptive of established cultural narratives. Multi- and intermediality allows us to overcome the notion of a text's "intended ideological meaning" (Klinger 4) to explore its potential for multiple and contrasting ideological meanings. However, as critics, we are well advised to not fall into what might be called the "Orientalist trap" by mistaking ideological multiplicity for merely divergent registers of traditional (Eurocentric) forms of Orientalism.

6 The authors of the volume engage the intricacies and contradictions of the discourse of Islamophobia in American mainstream culture through the study of multi- and intermedial configurations and through the concept of multi/intermedia dissensus. Arguably rid of the coarseness of twentieth-century anti-Muslim narratives, post 9/11 Islamophobia in the American mainstream media has fragmented into more digestible, more complex micronarratives dispersed across media, and sometimes across a text's multimedia structure. Post-9/11 Islamophobia begs us to modify Richard Dyer's statement that "the effectiveness of stereotypes resides in the way they invoke a consensus" (12) to make room for a new wave of stereotypes that thrive on in-text dissensus. Contributions in this special issue share the premise that 9/11 urges a scholarly reassessment of Orientalist discourse in an age characterized by the diversification of media and by their dense interrelations.

7 The contributions to this special issue elaborate on Islamophobia as a shapeshifting matter that permeates all media and inhabits the interstices between them. We 
approach Islamophobia with an emphasis on a variety of media including literature, television, film, graphic novels and performance art.

Stefan L. Brandt opens our special issue by putting his spotlight on the medium of literature. In his article "Fear of an Islamic Planet? Intermedial Exchange and the Rhetorics of Islamophobia" he argues that the post-9/11 era is marked by an unusual rise of Islamophobic rhetoric that permeates the U.S. cultural imaginary. It connects a wide range of medial discourses from literature and cinema to television and the World Wide Web. Orientalist stereotypes have informed Hollywood blockbusters and television series as well as acclaimed novels such as Khaled Hosseini's The Kite Runner (2003), John Updike's Terrorist (2006), and Mohsin Hamid's The Reluctant Fundamentalist (2007), not to mention Donald Trump's speeches and writings on "radical Islamic terrorism." Brandt argues that contemporary public discourse in the U.S. addresses an array of viral images, portraying Muslims as essentially 'alien' to mainstream American values. The fears of a potential-or already ongoing-"Islamization of America" are kept alive through continual interaction between texts and images from hegemonic visual discourse, involving "intermedial exchange" between literary texts, films, television shows, magazines, newspapers, and the Internet.

In her article "Inter/Multimedial Constructions of Islam in Post-9/11 TV Series: The West Wing and 24" Brigitte Georgi-Findlay explains that since The West Wing (NBC, 1999-2006), the political drama series has been a proliferating format for fictional engagements with American politics. Georgi-Findlay focuses on how The West Wing and 24 (Fox, 2001-2010) engage public narratives about Islam and Islamophobia, arguing that the shows go beyond what Evelyn Alsultany has termed "simplified complex representations" by creating contradictory, multivocal texts that display dynamics of internal disaccord. Representations of Arabs, Muslims and Muslim countries are embedded within storylines that challenge each other. Especially The West Wing stages discussions that can lead to informed debates, reflecting and exposing the contradictions within the American national identity discourse between an inclusionist civic and an exclusionist racialized nationalism. In both series, polyvocal narratives are brought across not only by intertwining multiple discourses, but also by way of aesthetic strategies and intermedial references that supply additional textual layers, complicating viewers' processes of meaning-making and contributing to in-text dissensus and ideological ambivalence. Both series can thus be read against the grain, as contradictory, multivocal texts that both reflect and expose Islamophobia.

10 Mahmoud Arghavan's "Islamophobia without Islamophobes: New Strategies of Representing Imperialist versus Suicide Terrorist Necropolitics in Homeland and Syriana" turns to the geopolitical context of the emergence of "suicide terrorism" to propose that terrorism in its various forms has less to do with religious ideologies in general and with Islamic faith in particular, and more to do with the colonial and neocolonial politics of Empire in the colonies, postcolonies and occupied territories by the U.S. army and its allies in the Middle East in the post-9/11 era. He analyzes two representations of suicide terrorists in the Showtime series Homeland (2011-) and the film Syriana (2005). Arghavan argues that even though the Islamicate world and Muslims in the post-9/11 era have generally been portrayed in a differentiated fashion, these media productions have had almost the same effects on the public as earlier Orientalist productions. Although they appear to endorse antiracism and multiculturalism on the surface, these current narratives simultaneously produce what 
Evelyn Alsultany calls "the logics and affects necessary to legitimize racist policies and practices" (Alsultany 162). A "dialectical Islamophobia" (Beydoun 40) that is at play in the West and Western media productions legitimizes and values, according to Arghavan, imperialist necropolitics while delegitimizing its opponent, namely the religious necropolitics of suicide terrorism.

"The Reluctant Islamophobes: Multimedia Dissensus in the Hollywood Premodern" by Elena Furlanetto contributes to the theorization of how Orientalism has evolved after $9 / 11$ and in the first two decades of the twenty-first century. She specifically addresses the multimediality of films and proposes that post-9/11 Orientalism has dispersed throughout the interplay of different media which constitute the film experience. Furlanetto recurs to Foucault's concept of dispositif to illustrate how any of these media -such as music, screenplay, editing, acting, etc.-may "[enter] into resonance or contradiction with the others" (Foucault 195), ambiguating the film's politics. When the film's different media pursue diverging politics, she speaks of multimedia dissensus. In order to test this hypothesis, Furlanetto focuses on two films which explicitly champion diversity and aim to reverse the logics of Islamophobia by presenting tributes to Muslim culture or denunciations of Eurocentric discriminatory practices: Alejandro Amenábar's Agora (2009) and Ridley Scott's Kingdom of Heaven (2005). A more detailed analysis of the films' multimedial complexity, however, shows that they do participate in the Islamophobic discourses that have dominated Hollywood cinema after $9 / 11$.

In Frank Mehring's analysis of "Islamophobia and Intermediality in Frank Miller's Graphic Novel" Holy Terror (2011) the graphic artist Frank Miller is framed as an innovative force in the field of graphic novels who pushes the medium into new territories. One such territory is Islamophobia and terrorism. Mehring explores how Islamophobia has been mediated and how media systems of the twenty-first century forge Islamophobia into new shapes asking: How does Frank Miller's aesthetics of silhouetted bodies reframe Islamophobia in an interpictorial and intermedial discourse of images? To what extent do Miller's graphic stylizations of Islamophobia remediate elements of his previous work on fictional (super)heroes and historical leaders from Batman to the 300 Spartans? He argues that Miller's visual narrative participates in the Islamophobic discourse of American popular culture by appropriating a wide array of popular culture visual archives for a propagandistic call for Muslim "Othering." Holy Terror references news media, films and television series, 9/11 photography, familiar comic book heroes, and, of course, Miller's own oeuvre. Thus, the graphic novel represents a kind of virtual agora where different media converge to engage in, shape and counter public discourses on Islamophobia. Mehring turns to the medium of graphic novels to first reveal how Miller's narratives and silhouette aesthetics of (super)heroes have become complicit with Islamophobic responses to the crisis of 9/11; second, to trace the discourse of Islamophobia in post-9/11 America in Miller's work; and, third, to reveal how this discourse interlinks with the patriotic logic of the fight against terrorism.

In "Challenging Islamophobia through Intermediality: Anida Yoeu Ali's Performance Art" Martina Pfeiler investigates Anida Yoeu Ali's performance art as that of a Muslim, Khmer-American feminist global agitator, who challenges Islamophobia in the United States and transnationally by expanding her work "into ever-widening arenas" (Fraser 82). Ali's performance projects formulate oppositional interpretations of Muslim 
"identities, interests, and needs" (Fraser 82) in an increasingly Islamophobic era from the aftermath of $9 / 11$ to Donald Trump's presidency. Drawing on theories of convergence culture and intermediality, Pfeiler provides a close analysis of Ali's performance projects. The first work is titled 1700\% Project: Mistaken for Muslim (2010), a performance poetry clip that was directed by the Japanese American filmmaker Masahiro Sugano and widely circulates on the Internet. It stands out as a feminist, transnational critique of an unprecedented "undermining [of] Muslim voices" (Azam 125). The article also includes an exploration of a selection of performance acts from Ali's The Red Chador Series $(2015 ; 2018 ; 2020)$. Pfeiler argues that by establishing discursive counternarratives the two works highlight the cultural potential of using intermediality to challenge private and public Islamophobia in a globally connected world. Thus, these works are explored as performative engagements with national, transnational, and gendered dimensions of Islamophobia.

\section{BIBLIOGRAPHY}

Abbas, Tahir. 2004. "After 9/11: British South Asian Muslims, Islamophobia, Multiculturalism, and the State.” The American Journal of Islamic Social Sciences, vol. 21, no. 3, 2004, pp. 26-38.

Alexander, Claire. "Raceing Islamophobia." Islamophobia: Still a Challenge for Us All. Runnymede Trust, 2017, pp. 13-16.

Allen, Christopher. Islamophobia. Ashgate, 2010.

Alsultany, Evelyn. Arabs and Muslims in the Media: Race and Representation after 9/11. New York UP, 2012.

Asen, Robert. "Seeking the 'Counter' in Counterpublics." Communication Theory, vol. 10, no. 4, November 2000, pp. 424-446.

Azam, Hina. "Islamic Feminism between Islam and Islamophobia." Journal of Middle East Women's Studies, vol. 14, no. 1, March 2018, pp. 124-128.

Beydoun, Khaled A. American Islamophobia: Understanding the Roots and Rise of Fear. U of California P, 2018.

Bleich, Erik. "Defining and Researching Islamophobia." Review of Middle East Studies, vol. 46, no. 2, 2012, pp. 180-189.

Bolter, Jay David and Richard Grusin. Remediation: Understanding New Media. The MIT Press, 1999. Bunglawala, Shenaz. “What's in a Name?” Islamophobia: Still a Challenge for Us All, Runnymede Trust, 2017, pp. 69-72.

“Donald Trump: ‘I Think Islam Hates Us.” CNN. Accessed 17 September 2020. https:// www.youtube.com/watch?v=C-Zj0tfZY6o.

Dyer, Richard. "The Role of Stereotypes." Media Studies: A Reader, edited by Paul Marris and Sue Thornham. Edinburgh UP, 1999, pp. 1-6. 
Elahi, Farah and Omar Khan. "Introduction: What Is Islamophobia?" Islamophobia: Still a Challenge for Us All. Runnymede Trust, 2017, pp. 5-12.

Fraser, Nancy. Justice Interruptus: Critical Reflections on the "Postsocialist" Condition. Routledge, 2014.

Halliday, Fred. 1999. “'Islamophobia' Reconsidered.” Ethnic and Racial Studies, vol. 22, no. 5, 1999, pp. 892-902.

Higgins, Dick. Horizons: The Poetics of Intermedia. 1998. Roof Books, 2007.

Iqbal, Zafar. "Islamophobia or Islamophobias: Towards Developing a Process Model." Islamic Studies, vol. 49, no. 1, Spring 2010, pp. 81-101.

Jenkins, Henry. Convergence Culture: Where Old and New Media Collide. New York UP, 2006.

Klinger, Barbara. "Digressions at the Cinema: Reception and Mass Culture." Cinema Journal, vol. 28, no. 4, Summer 1989, pp. 3-19.

Lee, Sherman A., Jeffrey A. Gibbons, John M. Thompson, and Hussam S. Timani. 2009. "The Islamophobia Scale: Instrument Development and Initial Validation." International Journal for the Psychology of Religion, vol. 19, no. 2, 2009, pp. 92-105.

Love, Erik. Islamophobia and Racism. New York UP, 2017.

Marr, Tim. "Islam and Transnationalism." The Cambridge Companion to Transnational American Literature (Cambridge Companions to Literature), edited by Yogita Goyal, Cambridge UP, 2017, pp. 251-268.

Miles, Robert, and Malcolm Brown. Racism. Psychology Press, 2003.

Neumann, Birgit. “Intermedial Negotiations: Postcolonial Literatures." Handbook of Intermediality: Literature-Image-Sound-Music, edited by Gabriele Rippl, De Gruyter, 2015, pp. 512-529.

Rippl, Gabriele. "Introduction." Handbook of Intermediality: Literature-Image-Sound-Music, edited by Gabriele Rippl, De Gruyter, 2015, pp. 1-31.

Runnymede Trust. Islamophobia: Still a Challenge for Us All. The Runnymede Trust, 2017. Accessed 15 July 2020. https://www.runnymedetrust.org/projects-and-publications/equality-andintegration/Islamophobia.html.

Salaita, Steven George. "Beyond Orientalism and Islamophobia: 9/11, Anti-Arab Racism and the Mythos of National Pride." The New Centennial Review, vol. 6, no. 2, Fall 2006, pp. 245-266.

Semati, Mehdi. "Islamophobia, Culture and Race in the Age of Empire." Cultural Studies, vol. 24, no. 2, 2010, pp. 256-75.

Zúquete, José Pedro. “The European Extreme-Right and Islam: New Directions?” Journal of Political Ideologies, vol. 13, no. 3, 2008, pp. 321-344.

\section{NOTES}

1. The term "Islamophobia" came to popularity in 1997, when the Runnymede Trust issued a report called Islamophobia: A Problem for Us All.

2. Regarding the word "Islamophobia" and its problematization, see Allen 135-138; Shenaz Bunglawala's "What's in a Name"; Miles and Brown, Racism.

3. Some scholars note that the target of Islamophobia is "Islam" as cultural universe (Zúquete 323; Semati 1, Alexander 13), some underline that Islamophobic sentiments can be triggered by individuals perceived as Muslim (Lee et al. 93; Abbas 28), and others claim that Islamophobia is 
exclusively directed against people, not religion (Halliday in Allen 135). It is also important to recognize that Islamophobic reactions may be triggered by markers of Otherness or, more specifically, perceived markers of Islam such as dress and appearance (see Love 11; Allen 125).

4. Allen argues that the focus on fear implicit in the etymology of Islamophobia and in most studies overlooks "more active and aggressive elements and activities" that characterize this phenomenon (136). See also Farah Elahi and Omar Khan, who agree with Allen that the pathological implications of phobia obscure "discriminatory attitudes and behaviours" (6). Beydoun dedicates the first pages of Islamophobia to fear as a result of anti-Muslim sentiments among Muslim communities in the U.S. "Our fear," Beydoun writes, "symbolize[s] the existential tightrope that defines Muslim American identity today. It has become a definitive part of what it means to be Muslim American" (6).

5. "I think Islam hates us," said Donald Trump in an interview with CNN's Anderson Cooper. https://www.youtube.com/watch?v=C-Zj0tfZY6o. See also Beydoun's discussion of Trump as "Islamophobia President" in American Islamophobia, pp. 8 and following.

6. In "Seeking the 'Counter' in Counterpublics" Robert Asen elaborates on the notion of "electronic agoras" in the framework of a critique of a singular, overarching public sphere in the sense of Habermas. For Asen, the agora is a flawed representation of the public sphere in so far as it "invokes a notion of publicity as contemporaneous face-to-face encounters among all citizens potentially affected by issues under consideration" (425). This model is, needless to say, unfitting for a highly mediatized public sphere rather defined by multiplicity and complex entanglements.

\section{AUTHORS}

\section{ELENA FURLANETTO}

Elena Furlanetto earned her doctorate in American Literary and Cultural Studies from the Technical University of Dortmund in July 2015 and currently works as a researcher at the University of Duisburg-Essen. She is the author of Towards Turkish American Literature: Narratives of Multiculturalism in Post-Imperial Turkey (2017) and a co-editor of A Poetics of Neurosis: Narratives of Normalcy and Disorder in Cultural and Literary Texts (2018). She has published on the influences of Islamic mystic poetry on Walt Whitman, on Islamophobia and the popularization of Islam in the US, and on the captivity narrative. Her research and teaching interests also include Orientalism, postcolonial literatures, comparative empire studies, and poetry. Elena Furlanetto is writing her postdoctoral thesis in the framework of the DFG Research Unit "Ambiguität und Unterscheidung: Historisch-kulturelle Dynamiken" (Ambiguity and Difference: Historical and Cultural Dynamics). Her focus are dynamics of 'ambiguation' in the early and nineteenth-century Americas.

\section{FRANK MEHRING}

Frank Mehring is chair and professor of American Studies at Radboud University, Nijmegen. He teaches twentieth- and twenty-first century visual culture, music, and theories of transatlantic studies. In 2012, he received from the European Association for American Studies the biennial Rob Kroes Award for his monograph The Democratic Gap (2014). His publications include Sphere Melodies (2003) on Charles Ives and John Cage, Soundtrack of Liberation (2015) on WWII sonic diplomacy, Sound and Vision: Intermediality and American Music (2018, with Erik Redling) The Mexico 
Diary: Winold Reiss Between Vogue Mexico and the Harlem Renaissance (2016), The Multicultural Modernism of Winold Reiss (2020), and The Politics and Cultures of Liberation (2018, with Hans Bak and Mathilde Roza). Frank is the co-founder of the European Digital Studies Network and the online journal AmLit - American Literatures (together with Stefan L. Brandt and Tatiani Rapatzikou). Frank is a board member of the International Committee of the American Studies Association, the European American Studies Association and the Netherlands American Studies Association. He organized the first international symposium on Winold Reiss in Berlin and cocurated exhibitions on Winold Reiss, the Marshall Plan, and Liberation Songs in New York, Nijmegen and The Hague. 